\title{
UNDERSTANDING BUSINESS PROCESSES WITH A LOOK AT A HOLISTIC-SYSTEMIC APPROACH TO CHANGE MANAGEMENT
}

\begin{abstract}
The subject of this paper is a theoretical background of the attitudes that treat the necessity of the importance of knowledge of business processes and holistic systemic approach to change management, in the broader context of strategic management, for better understanding and potential improvement of business by contemporary managers. The paper presents the general issues of strategic management and how it is artificially implemented in the business flows of modern organizations, then gives an overview of the concept of management by contemporary managers and issues related to the importance of knowing the characteristics of the business process and its management, and finally, provides an insight into the importance of change, as an important factor in the context of managing the business process of today, with an emphasis on a holistic-systems approach. The method of content analysis was used in the paper. The aim of the paper is to point out the importance of business process management in contemporary strategic management, above all in the context of growing changes and extremely dynamic and changing market environment, and to provide modern managers with insight into modern business and how to improve their business in an increasingly sharp market match.
\end{abstract}

Keywords: business process management, holistic-systemic approach, change management, strategic management, modern management

\footnotetext{
* Assistant Professor, University Business Academy in Novi Sad, Faculty of Economics and Engineering Management in Novi Sad, e-mail: gardasevic.jovana@gmail.com

** Assistant Professor, University Business Academy in Novi Sad, Faculty of Economics and Engineering Management in Novi Sad, e-mail: radic.maja@fimek.edu.rs
} 


\section{Introduction}

Ability to create vision, mission, goals and strategy, and their implementation in the life of the organization, change management, communicativeness, ability to constantly learn, intuitiveness, confidence, creation of new values, etc., are just some of the characteristics of the modern manager required by the new competition, new technology as well as a new lifestyle.

The subject of this paper is a theoretical background of the attitudes that treat the necessity of the importance of knowledge of business processes and holistic system approach to change management, in the broader context of strategic management, for better understanding and potential improvement of business by contemporary managers.

We are witnessing the phenomenon of globalization - a growing process in the business world with various influences of economy, politics and culture intertwining, hence it is necessary for the development, maintenance and improvement of the work of an organization to take this issue of business process management with a look at upcoming changes, as part of the strategic concept and framework, extremely seriously.

The aim of the paper is to point out the importance of business process management in contemporary strategic management, above all in the context of growing changes and extremely dynamic and changing market environment, and to provide modern managers with insight into modern business and how to improve their business in an increasingly sharp market match.

The research is significant because it provides a traditional and contemporary overview of the most important governing views in a given field in order to help modern managers to align and improve their operations according to theoretical frameworks.

\section{General Approach to Strategic Management}

The process of developing a strategy and allocating resources for its execution is often called 'strategic management'. ${ }^{1}$ Certo and Peter define strategic management as a continuous, iterative process aimed at keeping an organization as a whole appropriately matched to its environment. ${ }^{2}$ Igor Ansoff,

\footnotetext{
${ }^{1}$ Mintzberg, H. (1987). The strategy concept I: Five Ps for strategy. California Management Review, 30(1), pp. 11-24.

${ }^{2}$ Certo, C. S., Peter, J. P. (1991). Strategic Management: Concepts and Applications (2 $2^{\text {nd }}$ Ed.) New York, McGraw-Hill, p. 5.
} 
a distinguished professor who is rightly referred to by many as a strategic management guru, defines strategic management as a systematic approach to a major and increasing important responsibility of general management: to position and relate the firm to its environment in a way which will assure its continued success and make it secure from surprises. ${ }^{3}$

Tangible organizational action of any kind requires integration with the complete strategic management process; that is, when objectives are set, strategies are developed and execution is planned. ${ }^{4}$ The literature on strategic management presents a myriad of processes for how organizations should or could develop their strategies. ${ }^{5}$ Authors Brown and Melekpour in their paper described the three phases in generalized model of Strategic Management. ${ }^{6}$ First phase: The starting point of development of the objectives are the expected, or desired, outcomes. Once defined, the expected outcomes are often articulated in the form of specific and measurable objectives that the organization can work towards. ${ }^{7}$ Second phase: The options are then analyzed, based on external opportunities and threats, as well as the internal strengths and weakness. ${ }^{8}$ Third phase: The implementation phase involves an execution of the strategy. This phase is often the interface between the organization and its customers or clients, and is where the enterprise activity is observed by the broader society. ${ }^{9}$ Corporate social responsibility (CSR) is a wellestablished concept that primarily focuses on the need-or advantage-for organizations to consider and improve the positive societal impacts of their operations. ${ }^{10}$ The Strategic Management Process has also been used as a tool to facilitate organizational alignment and action. The application of the Strategic Management Process to fulfill businesses CSR obligations has also

\footnotetext{
${ }^{3}$ Ansoff, H. I., McDonnell, J. E. (1990). Implanting Strategic Management. New York, Prentice Hall, p. 10.

${ }^{4}$ Engert, S., Baumgartner, R. J. (2016). Corporate sustainability strategy-bridging the gap between formulation and implementation. Journal of cleaner production, 113, pp. 822-834.

${ }^{5}$ Bryson, J. M. (1988). A strategic planning process for public and non-profit organizations. Long range planning, 21(1), pp. 73-81.

${ }^{6}$ Grainger-Brown, J., Malekpour, S. (2019). Implementing the sustainable development goals: a review of strategic tools and frameworks available to organisations. Sustainability, 11(5), p. 1381.

${ }^{7}$ Malekpour, S., de Haan, F. J., Brown, R. R., (2016). A methodology to enable exploratory thinking in strategic planning. Technological Forecasting and Social Change, 105, pp. 192-202.

${ }^{8}$ Bryson op.cit., pp. 9.

${ }^{9}$ David, F., R. (2007). Strategic Management: Concepts and Cases. Upper Saddle River. New York, USA, Pearson Prentice Hall.

${ }^{10}$ Ballou, B., Heitger, D., Landes, C. (2006). The rise of corporate sustainability reporting: A rapidly growing assurance opportunity. Journal of Accountancy, 202(6), p. 65-74.
} 
been extended to include sustainable development. ${ }^{11}$ Successfully defining and implementing a corporate strategy in response to changes and demands of the environment in order to achieve successful performances and survival of the organization in the long run entails a very complex management system. ${ }^{12}$ When talking about a dynamic business environment, knowing the information from the immediate surroundings crucial for strategic management. Changes that occur in the external environment, especially in new technologies, affect strategy and planning in organizations. ${ }^{13}$ Therefore, we can see below the factors from the environment that influence strategic management in an organization or firm (Figure 1).

\section{Political Forces}

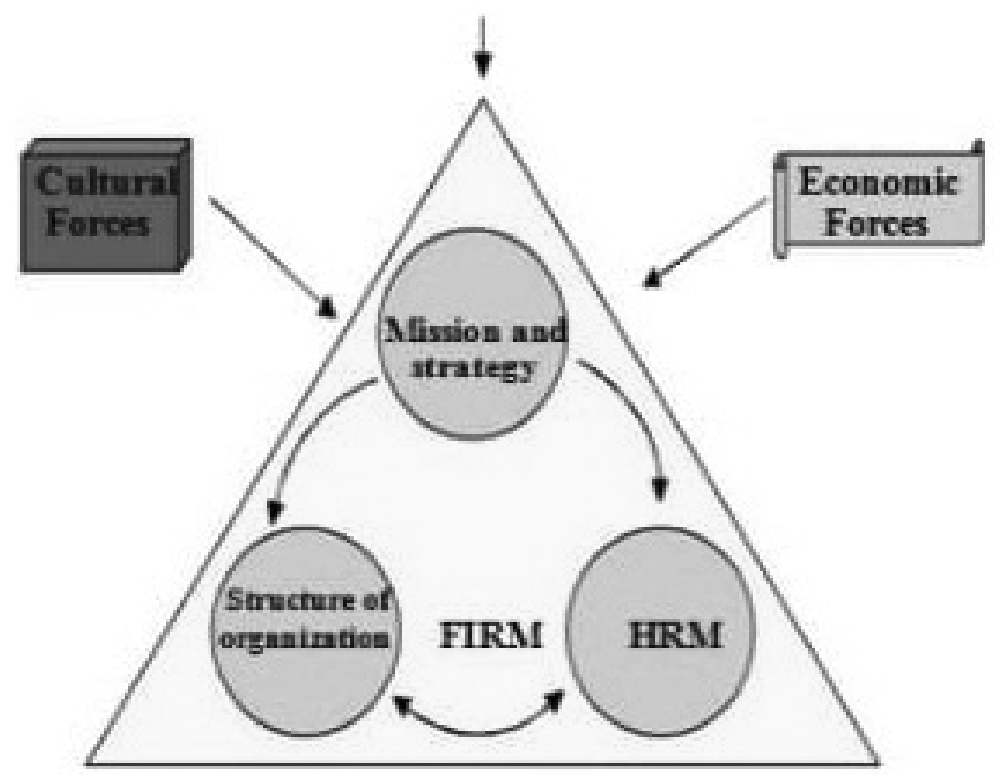

Figure 1 Strategic management and impacts of the environment Source: Author by Lojic, 2008.

\footnotetext{
${ }^{11}$ Baumgartner, R. J., Rauter, R. (2017). Strategic perspectives of corporate sustainability management to develop a sustainable organization. Journal of Cleaner Production, 140, pp. 81-92.

${ }^{12}$ Todosijevic, R. (2009). Strategijski menadžment - Metode i tehnike [Strategic Management Methods and Techniques]. Subotica, Ekonomski fakultet, p. 36.

${ }^{13}$ Zivanovic, N., Zivanovic, M., Zivanović, V. (2012). Menadžment procesima u funkciji planskih odluka [Process management in function of planning decisions]. Međunarodna naučna konferencija: Menadžment. Mladenovac, Srbija, pp. 761-764.
} 
Strategic management activities are directed toward establishing relationships between the organization and its environment, whereas operational management is focused on converting inputs into outputs in an organization. The front steps in the strategic management process can be seen in Figure 2.

Figure 2 The main steps in the strategic management process

\begin{tabular}{|l|l|l|l|l|}
$\begin{array}{l}\text { Step 1: } \\
\text { Analysis of the } \\
\text { environment } \\
\text { internal } \\
\text { external }\end{array}$ & $\begin{array}{l}\text { Step 2: } \\
\text { Directing the } \\
\text { organization } \\
\text { mission } \\
\text {-goals }\end{array}$ & $\begin{array}{l}\text { Step 3: } \\
\text { Formulating a } \\
\text { strategy }\end{array}$ & $\begin{array}{l}\text { Step 4: } \\
\text { Implementing } \\
\text { the strategy }\end{array}$ & $\begin{array}{l}\text { Step 5: } \\
\text { Strategic } \\
\text { control }\end{array}$ \\
\hline
\end{tabular}

Source: Author by Certo \& Peter, 1991.

I. Ansoff states that during the 20th century, with the increasing turbulence of the environment, firms developed more complex and detailed systems.

Two types of management systems have been developed ${ }^{14}$ :

- Positioning Systems and

- Real-Time Systems.

Strategic management is one side of the coin or responsibility that belongs to general management. The other side of the coin - responsibility is operational management. While strategic management deals with creating a strategic position that ensures the future life of an organization, operational management is concerned with utilizing the current strategic position to achieve the operational goals of the organization.

\section{Organization level, process level and activity level}

We define an organization as a social group of people that has its own structure and is managed so as to meet a particular need or to achieve common goals. ${ }^{15}$ In order to understand better how an organization "breathes" that is, how it really works, we need to explain first how it functions at the level of the entire organization, at the process level and at the activity level. Figure 3 shows the relationship between the goals set and the measure for performance evaluation, appropriate design and management at the level of organization.

\footnotetext{
${ }^{14}$ Ansoff, McDonnell, op.cit., p. 25.

${ }^{15}$ Markovic, A., Krmpot, V., (2014). Holističko-sistemski pristup upravljanju promenama [A holistic-systemic approach to change management]. Ekonomika, 60 (3), p. 150.
} 
Figure 3 Organization level - Relationship between set goals and measure for performance evaluation, appropriate design and management at the organization level

\begin{tabular}{|c|c|c|}
\hline $\begin{array}{c}\text { Goals and } \\
\text { measures }\end{array}$ & $\begin{array}{c}\text { Design and } \\
\text { implementation }\end{array}$ & Management \\
\hline $\begin{array}{l}\text { Goals of organization and measures of } \\
\text { success of an organization } \\
\text { Is the organization's } \\
\text { strategy set and delivered } \\
\text { to everyone? } \\
\text { Does the strategy make } \\
\text { sense in the conditions of } \\
\text { external risks and } \\
\text { opportunities and internal } \\
\text { strengths and weaknesses? } \\
\text { With this strategy, are the } \\
\text { required outputs of the } \\
\text { organization and the } \\
\text { expected level of } \\
\text { performance determined } \\
\text { for each output and } \\
\text { familiar? }\end{array}$ & $\begin{array}{l}\text { Design of the organization and } \\
\text { implementation } \\
\text { Are all relevant sections } \\
\text { and value chains in the } \\
\text { process architecture } \\
\text { described? } \\
\text { Are all sections and } \\
\text { processes necessary? } \\
\text { Is the current flow of } \\
\text { inputs and outputs between } \\
\text { sections, value chains and } \\
\text { key processes appropriate? } \\
\text { Does the formal } \\
\text { organizational structure } \\
\text { support strategy and } \\
\text { improve the system } \\
\text { efficiency? }\end{array}$ & $\begin{array}{cl}\text { Organization management } \\
\text { - } \\
\text { depe the appropriate goals of } \\
\text { depts set? } \\
\text { Are relevant performances } \\
\text { measured? } \\
\text { - Are resources allocated } \\
\text { appropriately? } \\
\text { Are connections between } \\
\text { departments managed? }\end{array}$ \\
\hline
\end{tabular}

Source: Author by Domazet, 2009.

Figure 4 tells us about the category of process levels in an organization. This figure shows the questions used to check whether the goals and measures, project solutions and way of management at the process level are mutually appropriate. This way it is checked whether a process has aligned the way it is designed and managed with the set goals and measures for the control of their achievement.

Figure 4 Process level - The link between goals and measures, design and implementation, and process-level management

\begin{tabular}{|c|c|c|}
\hline Goals and measures & Design and implementation & Management \\
\hline $\begin{array}{l}\text { Goals of processes and measures of } \\
\text { process success } \\
\text { Are the goals for key value } \\
\text { chains, processes and sub- } \\
\text { processes related to each other } \\
\text { as well as to the goals of } \\
\text { organization/customers? }\end{array}$ & $\begin{array}{l}\text { Process design and implementation } \\
\text { Are value chains and } \\
\text { business processes } \\
\text { decomposed into logical } \\
\text { and efficient processes and } \\
\text { sub-processes? } \\
\text { Are goals assigned to the } \\
\text { most efficient value chains, } \\
\text { processes and sub- } \\
\text { processes? }\end{array}$ & $\begin{array}{ll}\text { Process management } \\
\text { - } & \text { Are appropriate process sub- } \\
& \text { goals sets? } \\
\text { - Is process performance } & \text { managed? } \\
\text { - } & \text { Are sufficient resources } \\
& \text { allocated to each process? } \\
\text { - } & \text { Are connections between sub- } \\
& \text { processes and activities } \\
\text { managed? }\end{array}$ \\
\hline
\end{tabular}

Source: Author by Domazet, 2009. 
Figure 5 shows the questions used to check the extent to which goals and measures of success of activities are consistent with the project solutions for those activities and the planned way of managing the process activities.

Figure 5 Level of activities and performances - The link between the set goals and measures, design and management at the level of individual activity

\begin{tabular}{|c|c|c|}
\hline $\begin{array}{l}\text { Goals and } \\
\text { measures }\end{array}$ & Design and implementation & Management \\
\hline $\begin{array}{l}\text { Goals of activities and measures of } \\
\text { success of activities } \\
\text { Are outputs of activities and } \\
\text { standards aligned with process } \\
\text { requirements? (Which are } \\
\text { related to the requirements of } \\
\text { customers and organization?) }\end{array}$ & $\begin{array}{l}\text { Design of activities and } \\
\text { implementation } \\
\text { - Are the requirements of } \\
\text { activities reflected in the } \\
\text { system or job description of } \\
\text { the people to whom the } \\
\text { activity was assigned? } \\
\text { Are the steps of activities } \\
\text { given in a logical order? } \\
\text { Have good policies and } \\
\text { procedures been } \\
\text { developed? } \\
\text { Is the environment of the } \\
\text { activity acceptable from an } \\
\text { ergonomic point of view? }\end{array}$ & $\begin{array}{l}\text { Activity management } \\
\text { Do performers of activities } \\
\text { understand outputs of activities } \\
\text { and the standards they expect } \\
\text { to get? } \\
\text { Do performers have resources, } \\
\text { clear signals, priorities and } \\
\text { logically designed job? } \\
\text { Do performers know whether } \\
\text { they are achieving goals? } \\
\text { Are performers rewarded for } \\
\text { achieving the goals of } \\
\text { activities? } \\
\begin{array}{l}\text { Do performers have } \\
\text { knowledge/skill to accomplish } \\
\text { goals? }\end{array}\end{array}$ \\
\hline
\end{tabular}

Source: Author by Domazet, 2009.

\section{The importance of managing business processes}

Business process management primarily involves the following steps: setting goals, assigning tasks, reviewing results, improving processes, and taking corrective action, if necessary. Omissions in effective process management are a major cause of problems that occur in practice. Existing processes can be significantly improved by simply setting up a process management system or enhancing an existing business process management system. ${ }^{16}$ BPM (Business Processes Management) is a field of management that can be defined as a paradigm that includes methods, techniques, and tools to support the design, enactment, management and analysis of operational business processes. ${ }^{17}$

And when new business processes are implemented, it is crucial to have a good process management system to ensure their effective implementation.

\footnotetext{
${ }^{16}$ Domazet, D. (2009). Upravljanje procesima [Process Management]. Predavanje br. 3, pp. 7-16.

${ }^{17}$ Van Der Aalst, W. M. (2003). Business process management demystified: A tutorial on models, systems and standards for workflow management. In Advanced Course on Petri Nets Springer, Berlin, Heidelberg, pp. 1-65.
} 
How should a company organize managers to plan and control a process? Organizations that wish to manage processes need to form managers for their value chains and core business processes. ${ }^{18}$ The power of managers/leaders is very high. It is important to emphasize that the power of managers tends to grow steadily with the intensification of the globalization process. The size of the organization being managed, as well as the power it gives to the leader in its management, significantly influence, in combination with other factors, the way it is used in the process of decision-making and leadership of the organization. ${ }^{19}$ The manager sets the expectations of the process and determines how the process should be done and who should do it. When the process is executed, the manager looks at the outputs to see if they are within expectations, and if not, they take action to eliminate the problem. Furthermore, when it comes to the business process, its phases should also be taken into account. Specifically, a business process has 3 phases: 1 . Planning; 2 . Implementation and 3. Control. ${ }^{20}$

At present, there are a wide variety of software tools (named Business Process Management Suites, BPMS) that allow managing Business Process lifecycle to make easier BPM application in business environments. ${ }^{21}$ Nowadays, Business Process Management as a continuous improvement method is a common practice followed by a large number of organizations in all areas of business. ${ }^{22}$

\section{Challenges and changes and their impact on the organization's management}

Starting from the observed characteristics of our age, distinguished professor Igor Ansoff, whom we have already mentioned in our paper, who represents the leading authority of strategic management, points out that there are three consequences of accelerating the changes:

- Increasing difficulties in anticipating and responding to problems in a timely manner,

\footnotetext{
${ }^{18}$ Domazet, op.cit., p. 6.

${ }^{19}$ Prodanovic, R, Gardasevic, J., Softic, M. (2019). Percepcije zaposlenih o korišćenju liderske moći u organizaciji [Employee perceptions of using leadership power in an organization]. IX Međunarodni poljoprivredni simpozijum „Održivi razvoj savremene poljoprivredne proizvodnje“, Kragujevac, Visoka škola za menadžment i ekonomiju; Banja Luka, Univerzitet za Poslovne studije; Beograd, Centar za održivi razvoj, p. 153.

${ }^{20}$ Domazet, op.cit., pp. 7-16.

${ }^{21}$ Van Der Aalst, op.cit., p. 3.

${ }^{22}$ Meidan, A., García-García, J. A., Escalona, M. J., Ramos, I. (2017). A survey on business processes management suites. Computer Standards \& Interfaces, 51, pp. 71-86.
} 
- The need to increase implementation speed of response to change and

- The need for flexible and timely responses to surprises that cannot be anticipated in advance. ${ }^{23}$

The humanity faces the deepest social change and creative restructuring to date, and as A. Toffler states, we have already got down to creating a new civilization from the ground up. This is the meaning of the so-called third wave. ${ }^{24}$ Acceleration of change is particularly conditioned by technological changes, which include changes in products (services), processes and today information technologies, as basic prerequisites for the success of organizations. A modern organization needs to incorporate into its structure: change management and organized abandonment of everything it does, but also the ability to create the new. ${ }^{25}$

Bill and Roy Richardson are well aware that the business environment of the organization changed completely in the 1990s compared to the situation of 25 years ago. ${ }^{26}$

The new age we live in and the new production system (production and consumption of goods and services) differ from the old in the following characteristics: ${ }^{27}$

1. High production diversification and continuous innovation of both products and process, bringing the product closer to the very specific needs of highly individual consumption;

2. Production for an unknown customer (uniform, which needs to be imposed) is replaced by production for a known consumer; 3 . Enrichment of functions, increase of reliability and quality, development of service content and the aesthetic component of the product; 4. Increasing intellectualization of production processes accompanied by a decrease in energy and material intensity, enrichment of work, widening the range

\footnotetext{
${ }^{23}$ Ansoff, McDonnell, op.cit., pp. 9-11.

${ }^{24}$ Toffler, A. (1983). Treći talas [Third wave]. Beograd, Prosveta, p. 28

${ }^{25}$ Drucker, F. P. (1995). Postkapitalističko društvo [The Post-Capitalist Society]. Beograd, GrmečPrivredni pregled, pp. 63-64.

${ }^{26}$ Richardson, B., Richardson, R., (1989). Business Planning: An Approach to Strategic Management. London, Pitman, p. 22.

${ }^{27}$ Matejic, V. (1994). Novi proizvodni sistem na globalnom nivou i kultura na jugoslovenskom prostoru: ishodi najverovatnijih evolucija izazova i promena i njihov uticaj na menadžment organizacije interakcija [New global production system and culture in Yugoslavia: outcomes of the most likely evolutions of challenges and changes and their impact on the management of interaction organizations]. I Naučni skup: Tehnologija, kultura i razvoj, Beograd, Institut "Mihajlo Pupin”, pp. 118-119.
} 
of required knowledge and expertise and democratization of the work process; 5. Large and complex technical, production, business and other capacities that are easily restructured because they are slightly hierarchized, with a predominantly network structure, rapid adaptation and efficient internationalization and outsourcing of activities and functions; 6. High dynamics of new, largely artificial, scientific-based new inputs, new work processes and new goods and services; 7. High mobility, easy transferability and easy accessibility of all production factors, increasing multiculturality of production process, fast and relatively cheap global communication, selection and distribution of goods and services globally; 8 . A growing positive attitude towards the preservation of material and biological creation on earth and the generation of entirely new problems directly affecting man (problems related to artificial intelligence and robotics; multimedia manipulation of information, images and notion of reality; erasing the clear boundaries between illusion and reality the development of corporations and economy of spectacle, etc.); 9. Growth and accumulation of knowledge instead of physical capital; 10. Development of technological and administrative capacities for social needs (disabled, the elderly, long periods of idleness, frequent intervals between employment, etc.); 11. Teleworking and the emergence of a virtual corporation; 12. Weakening and abandoning "work ethic" and some other civic values.

Taken into consideration the current state of the information society and the rapid growth of information technologies in the early twenty-first century, we can assume that the information management is the present and future of the world economy. ${ }^{28}$

\section{A holistic-systemic approach to change management}

In order to understand the functioning of goal-aware organizational systems, we need to abandon the classical approach in explaining how they function, which is the Cartesian, mechanistic approach. The functioning of the whole can no longer be interpreted based on an understanding of how the parts work. A holistic approach means an approach where the whole is more important than its constituent parts. Although holism is a concept largely

\footnotetext{
${ }^{28}$ Eroshkin, S. Y., Kameneva, N., Kovkov, D., Sukhorukov, A. (2017). Conceptual system in the modern information management. Procedia Computer Science, 103(C), pp. 609-612.
} 
present in many spheres of human activities and interests, such as medicine, philosophy, sociology, education, it has been mentioned only recently in the business sphere. ${ }^{29}$ The holistic perspective of organizations is commonly referred as "corporate social responsibility" 30

Managing changes means that, since everything around us is constantly changing (now faster and on a much larger scale) we need to change (transform, improve) our own selves and organization in order for this new, changed state to fit the new conditions set before us. ${ }^{31}$ In a holistic approach to management, it is essential that all relevant management decisions are at the same time good for the organization as a whole, when the organization is viewed from all aspects: economic, social, environmental and from the point of view of human resources. Decisions can no longer be solely goal-oriented; they need to strive for a holistic context. A holistic context for an organization is a context that encompasses all the goals and actions that lead to the realization of the vision, or mission, for which the organization was initially founded. ${ }^{32}$

In the new economy, the organization is becoming increasingly flexible, and this has been driven by the need for change to overcome the impact of the environment. This requires that the organization no longer has only a hierarchical (vertical) model of organization, but models of decentralized (horizontal) structures are increasingly developing. Enterprise organization is becoming more straight-line, that is, a structure based on decentralized and fragmented organizational segments that are significantly more flexible, more mobile, and thus easily accessible for management. ${ }^{33}$

According to Marković and Krmpot, change management is how organizations today achieve the goals they were founded for. When managing a change, it is important for leaders to be aware of the following facts that always accompany the initiation of change: - dissatisfaction with the results achieved; - dissatisfaction with the strategies implemented so far; - the existence of a vision of better solutions that can and must be communicated and explained to others; - existence of a strategy for implementing the change and achieving the desired state; - resistance to change is always present, but it can be overcome.

\footnotetext{
${ }^{29}$ Markovic, Krmpot, op.cit., pp. 149-150.

${ }^{30}$ Grainger-Brown, Malekpour, op.cit., p. 5.

${ }^{31}$ Markovic, Krmpot, op.cit., pp. 149-150.

${ }^{32}$ Djordjevic, B. (1993). Osnove menadžmenta [Fundamentals of Management]. Niš, Sirius, p. 397.

${ }^{33}$ Djordjevic, op.cit., p. 397.
} 
How and with what tools to tackle change management as part of modern management? Change management is, in fact, the order of a series of processes that are initiated to ensure the implementation of significant changes in a systematically and controlled manner. The reason for this is that, as soon as we have completed one, we need to initiate and manage other changes over and over again. A set, sequence and proper series of processes and adequately established relationships will help to achieve the same result when initiating and managing the next change. ${ }^{34}$ Change management plays a critical role in today's organization, not only in maintaining variation of existing operations, but also in shaping the future directions of an organization. A number of change management models or processes are available: ${ }^{35}$ (1) Preparing for the change, including analyzing, planning, and strategy development, (2) Managing change implementation, (3) Consolidating and institutionalizing the change, including change review, feedback analysis, corrective action, and stabilize the implemented change.

\section{Conclusion}

Strategic management is embraced and practiced by businesses facing an increasingly volatile, turbulent and complex environment. The task of strategic management is, therefore, to enable the organization to respond rationally and in a timely manner to changes in the environment. In this sense, strategic management includes: strategic planning as its essential part (strategic analysis and strategic choice), but also strategic change (strategic implementation and control).

Andersen's empirical study provides evidence that strategic planning (that emphasizes elements of the conventional strategic management process) is associated with higher performance in all the industrial environments studied. The performance effect of strategic planning does not vary significantly between the different industry groups. Hence, strategic planning is an important performance driver in all industrial settings, and enhances both economic performance and organizational innovation. ${ }^{36}$

\footnotetext{
${ }^{34}$ Markovic, Krmpot, op.cit., p. 155.

${ }^{35}$ Tang, K. N. (2019). Change management. In: Leadership and Change Management, Springer, Singapore, pp. 47-55.

${ }^{36}$ Andersen, T. J. (2000). Strategic Planning, Autonomous Actions and Corporate Performance. Long Range Planning, 33(2), pp. 184-200.
} 
Organizations that want to manage processes need to form managers for their value chains and core business processes. Process management is the practice of managing, controlling and improving business processes.

When it comes to change, it is crucial to keep in mind that the acceleration of change is especially conditioned by technological changes which encompass changes in products (services), processes, and information technology today, as basic prerequisites for the success of organizations.

A holistic approach allows refining the strategy as a set of cause and effect relationships that are good for the organization as a whole. This requires that managers identify the activities that act as drivers of the desired results. An organization needs to respond to new conditions, the newly changed environment in a proactive, carefully prepared and meticulously measured manner. Functional areas of a system need to be aware of how their activities affect other components of the system and the entire system.

Therefore, in this paper we have outlined all the important characteristics of strategic management, process management, and we put special emphasis on the holistic-systematic approach to change management, crucial for the time of changes in which we live. The research is significant because it provides a traditional and contemporary overview of the most important governing views in a given field.

This paper is intended to modern managers with a purpose to help them to gain insight into the traditional and contemporary postulates of strategic management, business process, and a holistic approach to change management in order to improve their managerial business.

The lack of this paper work is reflected in the lack of empirical research, therefore, the possibility of conducting empirical research is taken into consideration, as a direction for the further research. 


\section{Gardašević Jovana}

Docent, Fakultet za ekonomiju i inženjerski menadžment u Novom Sadu, Univerzitet

Privredna akademija u Novom Sadu

\section{Radić Maja}

Docent, Fakultet za ekonomiju i inženjerski menadžment u Novom Sadu, Univerzitet Privredna akademija u Novom Sadu

\section{RAZUMEVANJE POSLOVNIH PROCESA SA OSVRTOM NA HOLISTIČKO-SISTEMSKI PRISTUP UPRAVLJANJU PROMENAMA}

REZIME: Predmet rada je teorijski prikaz stavova koji tretiraju neophodnost značaja poznavanja poslovnih procesa i holističko-sistemskog pristupa upravljanja promenama, u širem kontekstu strategijskog menažmenta, radi boljeg razumevanja i potencijalnog poboljšanja poslovanja od strane savemenih menadžera. Rad prezentuje opšta pitanja startegijskog menadžmenta i način njegove umešne implementacije u poslovne tokove modernih organizacija, zatim daje osvrt na pojam upravljanja od strane savremenih menadžera te pitanja koja se tiču značaja poznavanja karakteristika poslovnog procesa i upravljanja istim, a na kraju, pruža uvid o značaju promena, kao bitnom faktoru u kontekstu upravljanja poslovnim procesom današnjice, sa akcentom na holističko-sistemskim pristup. U radu je korišćen metod analize sadržaja. Cilj rada je da ukaže na značaj upravljanja poslovnim procesima u savremenom startegijskom menadžmentu, a pre svega u kontekstu rastućih promena i izuzetno dinamičnog i promenljivog tržišnog okruženja te da, kroz prikaz savremene literature i analizu sadržaja pruži uvid modernim menadžerima kako da poboljšaju svoje poslovanje u sve oštrijoj tržišnoj utakmici.

Ključne reči: upravljanje poslovnim procesima, holističko sistemski proces, upravljanje promenama, strateški menadžment, savremeni menadžment 


\section{References}

1. Andersen, T. J. (2000). Strategic Planning, Autonomous Actions and Corporate Performance. Long Range Planning, 33(2), pp. 184-200

2. Ansoff, H. I., McDonnell, J. E., (1990). Implanting Strategic Management. New York, Prentice Hall

3. Ballou, B., Heitger, D., Landes, C., (2006). The rise of corporate sustainability reporting: A rapidly growing assurance opportunity. Journal of Accountancy, 202(6), pp. 65-74

4. Baumgartner, R. J., Rauter, R. (2017). Strategic perspectives of corporate sustainability management to develop a sustainable organization. Journal of Cleaner Production, 140, pp. 81-92

5. Bryson, J. M. (1988). A strategic planning process for public and non-profit organizations. Long range planning, 21(1), pp. 73-81

6. Certo, C. S., Peter, J. P. (1991). Strategic Management: Concepts and Applications ( $2^{\text {nd }}$ Ed.) New York, McGraw-Hill

7. David, F. R. (2007). Strategic Management: Concepts and Cases. Upper Saddle River, New York, USA, Pearson Prentice Hall.

8. Domazet, D. (2009). Upravljanje procesima [Process Management]. Predavanje br. 3, pp. 1-55

9. Drucker, F. P. (1995). Postkapitalističko društvo [The Post-Capitalist Society]. Beograd, Grmeč-Privredni pregled

10. Djordjevic, B. (1993). Osnove menadžmenta [Fundamentals of Management]. Niš, Sirius

11. Engert, S., Baumgartner, R. J.,(2016). Corporate sustainability strategybridging the gap between formulation and implementation. Journal of cleaner production, 113 , pp. 822-834

12. Eroshkin, S. Y., Kameneva, N., Kovkov, D., Sukhorukov, A. (2017). Conceptual system in the modern information management. Procedia Computer Science, 103(C), pp. 609-612

13. Grainger-Brown, J., Malekpour, S. (2019). Implementing the sustainable development goals: a review of strategic tools and frameworks available to organisations. Sustainability, 11(5), p. 1381

14. Lojic, R. (2008). Savremene tendencije u oblasti menadžmenta ljudskih resursa [Contemporary tendencies in the field of human resources management]. Vojno delo, (1), pp. 156-174

15. Malekpour, S., de Haan, F. J., Brown, R. R. (2016). A methodology to enable exploratory thinking in strategic planning. Technological Forecasting and Social Change, 105, pp. 192-202 
16. Markovic, A., Krmpot, V. (2014). Holističko-sistemski pristup upravljanju promenama [A holistic-systemic approach to change management]. Ekonomika, 60 (3), pp. 149-160

17. Matejic, V. (1994). Novi proizvodni sistem na globalnom nivou i kultura na jugoslovenskom prostoru: ishodi najverovatnijih evolucija izazova $i$ promena i njihov uticaj na menadžment organizacije interakcija [New global production system and culture in Yugoslavia: outcomes of the most likely evolutions of challenges and changes and their impact on the management of interaction organizations]. I Naučni skup: Tehnologija, kultura i razvoj, Beograd, Institut "Mihajlo Pupin", pp. 118-119

18. Meidan, A., García-García, J. A., Escalona, M. J., Ramos, I. (2017). A survey on business processes management suites. Computer Standards \& Interfaces, 51, pp. 71-86

19. Mintzberg, H., (1987). The strategy concept I: Five Ps for strategy. California management review, 30(1), pp. 11-24

20. Prodanovic, R., Gardasevic, J., Softic, M., (2019). Percepcije zaposlenih o korišćenju liderske moći u organizaciji [Employee perceptions of using leadership power in an organization]. IX Međunarodni poljoprivredni simpozijum „Održivi razvoj savremene poljoprivredne proizvodnje“, Kragujevac, Visoka škola za menadžment i ekonomiju; Banja Luka, Univerzitet za Poslovne studije; Beograd, Centar za održivi razvoj, pp. 145-155

21. Richardson, B., Richardson, R. (1989). Business Planning: An Approach to Strategic Management. London, Pitman

22. Tang, K. N. (2019). Change management. In: Leadership and Change Management Springer, Singapore, pp. 47-55

23. Todosijevic, R. (2009). Strategijski menadžment - Metode i tehnike [Strategic Management - Methods and Techniques]. Subotica, Ekonomski fakultet

24. Toffler, A. (1983). Treći talas [Third wave]. Beograd, Prosveta

25. Van Der Aalst, W. M. (2003). Business process management demystified: A tutorial on models, systems and standards for workflow management. In Advanced Course on Petri Nets Springer, Berlin, Heidelberg, pp. 1-65

26. Zivanovic, N., Zivanovic, M., Zivanovic, V., (2012). Menadžment procesima $u$ funkciji planskih odluka [Process management in function of planning decisions]. Međunarodna naučna konferencija: Menadžment. Mladenovac, Srbija, pp. 761-764 